\title{
PROPAGANDA: A STRATEGY TO SPREAD THE IDEOLOGY IN PAKISTAN IN THE NOVEL I AM MALALA BY MALALA YOUSAFZAI AND CHRISTINA LAMB (2013)
}

\author{
Ruly Kartika ${ }^{1,3}$, Sri Warsidah Rahmi ${ }^{2,4}$ \\ ${ }^{1}$ UIN Alauddin Makassar \\ ${ }^{2}$ Universitas Indonesia \\ ${ }^{3}$ rulykartika09@gmail.com \\ ${ }^{4}$ sriwarsidahchannel@gmail.com
}

\begin{abstract}
This study examines the analysis of propaganda in the literature as revealed in the novel I Am Malala. The purpose of this research is to analyze and depict Taliban's Taliban propaganda as a strategy to gain power in Pakistan. Their strongest effort is to spread propaganda throughout the community to the region. The propaganda theory, Jacques Ellul, is used to find out how the Taliban use propaganda as their strategy and to know the qualitative methods related to the description and explanation of the phenomenon of propaganda. Through this research, the author discovers the type of propaganda created by the author to clarify the conflict that has occurred between the Taliban and the community. Then, the author gives the propaganda purpose. This study implies how propaganda has become a social phenomenon of life and implicitly forms a perspective in viewing around the community.
\end{abstract}

Keywords: Propaganda, Taliban, Pakistan

\section{Abstract}

Penelitian ini mempelajari tentang analisis propaganda dalam literatur seperti yang terungkap dalam novel I Am Malala. Tujuan dari penelitian ini adalah untuk menganalisis dan menggambarkan propaganda Taliban yang dilakukan Taliban sebagai strategi untuk mendapatkan kekuasaan di Pakistan. Upaya terkuat yang mereka lakukan adalah menyebarkan propaganda ke seluruh masyarakat ke daerah. Teori propaganda, Jacques Ellul, digunakan untuk mengetahui cara Taliban menggunakan propaganda sebagai strategi mereka dan untuk mengetahui metode kualitatif yang berkaitan dengan deskripsi dan penjelasan fenomena propaganda. Melalui penelitian ini, penulis menemukan jenis propaganda yang diciptakan oleh penulis untuk mengklarifikasi konflik yang telah terjadi antara Taliban dan masyarakat. Kemudian, penulis memberikan tujuan propaganda itu. Penelitian ini berimplikasi bagaimana propaganda telah menjadi fenomena sosial kehidupan dan secara implisit membentuk perspektif dalam melihat sekitar masyarakat.

Keywords: Propaganda, Taliban, Pakistan

\section{INTRODUCTION}

From 1995 to 2001, the Pakistani inter-services intelligence and military are widely alleged by the international community to have provided support to the Talliban. Their connections are possibly through Harkat-ul-Mujahideen, a terrorist group founded by Sami ul Haq. Pakistan is accused by many international officials of continuing to support the Taliban; Pakistan states that it dropped all support for the group after 9/11. Al-Qaeda also supported the Taliban with regiments of imported 
fighters from Arab countries and Central Asia. Saudi Arabia provided financial support. The Taliban and their allies committed massacres against Afghan civilians, denied UN food supplies to 160,000 starving civilians and conducted a policy of scorched earth, burning vast areas of fertile land and destroying tens of thousands of homes during their rule from 1996 to 2001. Hundreds of thousands of people were forced to flee to United Front-controlled territory, Pakistan, and Iran.

After the attacks of September 11, 2001, the Taliban were overthrown by the American-led invasion of Afghanistan. Later it regrouped as an insurgency movement to fight the American-backed Karzai administration and the NATO-led International Security Assistance Force (ISAF). The Taliban have been accused of using terrorism as a specific tactic to further their ideological and political goals. According to the United Nations, the Taliban and their allies were responsible for $75 \%$ of Afghan civilian casualties in $2010,80 \%$ in 2011 , and $80 \%$ in 2012.

Actually The Taliban is an Islamic movement following a strict interpretation of Sharia that took over Afghanistan following the Soviet withdrawal. Taliban rule imposed draconian restrictions on women being allowed to work, go to school, or even leave the house -- which could only be done fully covered with a burqa and accompanied by a male relative. The Taliban granted safe haven to terrorist group alQaida, leading to their overthrow by a U.S.-led invasion in 2001. The Taliban have regrouped in the mountainous region straddling Pakistan and Afghanistan, and have continued to operate as an insurgent movement.

Taliban spread throughout Afghanistan and formed a government, ruling as the Islamic Emirate of Afghanistan from September 1996 until December 2001, with Kandahar as the capital. However, it gained diplomatic recognition from only three states: Pakistan, Saudi Arabia, and the United Arab Emirates. Mohammed Omar is the founder and has been serving as the spiritual leader of the Taliban since its foundation in 1994. While in power, it enforced a strict interpretation of Sharia, or Islamic law, an interpretation of which leading Muslims have been highly critical. The Taliban were condemned internationally for their brutal treatment of women.

The above events are important to be discussed considering suffer experienced by the oppressed Pakistani society in their very own country. This is proven from the number of literary works that emerged as a result of the event. In other words, literary works became a medium to illuminate the suffering experienced by the people of Pakistan.

Literary work is an author's creative thinking. The author writes the literary work based on what he feels, sees, and experiences in real life. It is a reflection of real life. Although the form is fiction, such as short story, novel, and drama, the issues presented by the author cannot be separated from everyday real life experiences. Therefore literary works can be a potrait of life through the characters, plot, and setting of the story (Aristotle in Davis, 2002:3).

Furthermore, a novel is sometimes used by an authority or a group to convey the doctrine to others as well as the propaganda used by the people in their society to 
convey a doctrine to others. According to Gramsci (1971:367), propaganda is a power or domination over life values, norms, and cultural group of people who eventually turns into a doctrine of the other communities where the group is dominated by consciously followed. Meanwhile, according to Ellul (1965:62), propaganda refers to the management and the control of people's behaviours, and beliefs. It is a medium to set and plant particular ideas in to the community to gain approval for the ruling group. In other words, propaganda is a way to influence others to follow our will which uses words or sentences. Through propaganda, a person can change the mindset of someone about something.

The writer is, therefore, interested in analyzing propaganda in novel "I Am Malala" by Malala Youzafsai and Christina Lamb. This novel tells about the girl who stood up for education and was shot by the Taliban. When the Taliban took control of the Swat Valley in Pakistan, Malala spoke out. She refused to be silenced and fought for her right to an education. On Tuesday, October 9, 2012 when she was fifteen, she almost paid the ultimate price. She was shot in the head at point-blank range while riding the bus home from school, and few expected her to survive. Malala was shot with the intention killed by the Taliban, because she is a girl who dared to challenge the Taliban forbade girls school. No matter she is just a teenage girl who was only 16 years old. When the Taliban under the leadership of Maulana Fazlullah, who controlled Swat banned all girls school. It makes the writer interested in analyzing the study of propaganda by applying Ellul's theory of propaganda.

Based on the background above, the focuses of this research is to show the kinds of the propaganda which presented in the novel of "I Am Malala" and how the impact vonveyed through the propaganda in the novel "I Am Malala".

\section{THEORETICAL FRAMEWORK}

\section{A. Communication Theory}

Communication is the process of delivering thoughts or feelings by one person to another by using signs that are meaningful to both parties. In certain situations, communication uses certain media to change the attitude or behavior of someone or some people to achieve certain goals (Miller, 2005: 13).

One of the theoreticians of mass communication as well as the most famous is Harold Lasswell. He puts forward a model of communication which is simple and often quoted by a lot of people. The model consists of five elements (Muth, 2004: 117-120) as follows:

\section{Who? (source)}

Communicators are the main actors/parties who have a need to communicate or initiate a communication. It can be an individual, group, organization, or a country.

2. Says what? (message)

Message refers to what will be delivered/communicated to the recipient (communicant) from the source (communicator) or information content. It is a symbol of a set of verbal/non-verbal that represent feelings, values, ideas/intention of the source. There are three components of the message that is the intention of the source. 
There are three components of the message that is the meaning, symbols to convey meaning, and from/organozation of the message.

3. In which channel? (channel/media)

Tool/medium conveys the message of the communicator (source) to communicant (receiver) directly (face to face), or directly (through printed/electronic media).

4. To whom?

Receiver is the person / group / organization / the country that receives the message from the source.

5. With what effect? (impact/effect)

Impact/effect occurs to the communicant (receiver) after receiving a message from a source, such as a change in attitude, increasing knowledge, etc.

\section{B. Rhetoric}

Rhetoric as art to speak has a relationship with the communication process. Communication in this context is a process of delivering information from the communicator to the communicant, so that communicants understand what is intended and what is desired by the communicator. In rhetoric, the communication process is very important. A retort must be able to communicate the content of the message properly and effectively to public. Thus, a retort must understand communication patterns used in delivering the content of the message, and those communication patterns can be known from the type of audience who will be listening. This is important to achieve effective communication (Gardina, 2005:113).

Language factor very important as well, if the two parties understand each other when using the same language. Thus, the rhetoric would not be separated from the process of communication, and it can be said that communication is absolutely a part of the rhetoric.

\section{Propaganda Theory}

Propaganda gives a way, how to suggest the other people until he can follow our mind or destiny. According to Gramci (1971: 400) propaganda is used as a process of mastering the dominant class to lower class and lower class are also actively supporting the ideas of the dominant class. Here the control is done not by force, but through consent forms dominated society. While, Lasswell (in Graham, 2006: 43) says that "propaganda is the management of collective attitudes by the manipulation of significant symbols". Propaganda is used as a way to instill trust in the community to be able to follow all the wishes of the ruling group.

According to Morley (2002:44), propaganda is a kind of persuasive communication that used in as tates where there are totalitarian governments and cannot exist in a true democracy. Malesevie (2010:203), states that propaganda is a strenuous reproduction form of organized communication involving production, reproduction and dissemination of ideas, images and messages that are aimed at persuading and influencing the opinions and actions of large groups of individuals. Coxall (2013) states that propaganda is defined as the dissemination of information 
which is favorable to the objectives of the manipulator but which omits information which is unfavorable. The information distributed in propaganda is normally accurate as far as it goes, but the reports issued by a manipulator are incomplete, and whatever facts considered contrary to the manipulator's interests are filtered out before transmission to the victim. Having the similar idea of propaganda to Coxall, Smith in Marlin (2013: 9) defines propaganda is "the more or less systematic effort to manipulate other people's beliefs, attitudes, or actions by means of symbols". It can be done through words, gestures, banners, monuments, music, clothing, insignia, hairstyles, designs on coins and postage stamps, and so on. The emphasizing on the deliberateness and manipulation makes propaganda is different from casual conversation or the free and easy exchange of ideas.

Propaganda is the deliberate and systematic attempt to shape perceptions, manipulate the minds, and direct behavior to get the desired reaction disseminators of propaganda. (O'Donnell, 2005:50). Propaganda sometimes conveys the actual message, but the content is often misleading in which it generally only conveys facts that can produce a certain effect, or more emotional reactions than rational reaction. The goal is to change the mind of the cognitive narrative of the subject in the target audience for a particular interest. Therefore, propaganda is a deliberate and systematic attempt to shape perceptions, manipulate the mind or cognition, and directly affect the behavior to provide the desired response of the propagandist.

As a one to many communication, propaganda separates the communicator from the communicant. However, according to Ellul, a communicator in propaganda is actually a representative of an organization that seeks controlling toward the communicant group. It can be concluded that a communicator in propaganda is an expert in social control. With a wide range of technical skills, each ruler of the country or those who aspire to become the ruler of the country must use propaganda as a means of social control mechanisms (Nelson, 2006: 25)

Jacques Ellul (1965: 70-79), furthermore, defines a propaganda as communication "used by an organized group that wants to create active or passive participation in the actions of a mob psychologically made up of individuals and united in an organization. According to him, propaganda is closely related to the organization and action, which is practically non-existent without the propaganda. $\mathrm{He}$ divides propaganda into four types:

1. Propaganda of Agitation

In the case of agitprop, the ideas to be disseminated were those of communism, including explanations of the policy of the Communist Party and the Soviet state. In other contexts, propaganda could mean dissemination of any kind of beneficial knowledge, e.g., of new methods in agriculture. Agitation meant urging people to do what Soviet leaders expected them to do; again, at various levels. In other words, propaganda was supposed to act on the mind, while agitation acted on emotions, although both usually went together, thus giving rise to the cliché "propaganda and agitation". 
Propaganda of agitation is a movement done to gain sympathy, acceptance of ideas, and the spread of desires, and demands that influence the masses to participate in the movement, in the organization or make changes. Propaganda agitation attempts to arouse the attention or encourage others to conduct a systematic plan or joint movement for the dissemination of a belief or doctrine. Propaganda agitation focuses on the actual issues that are trying to push an action againts the issue. Propaganda deals with the explanation of ideas detailed and more systematic. Therefore, it is clear that the agitation and propaganda are two closely related matters.

2. Propaganda of Integration

Propaganda of integration another form of propaganda which is instilling confidence to others based on the belief or knowledge they already have before. In general, this type of propaganda used religion as a bridge, because religion is the doctrine of the strongest for all believers. Propaganda of integration mobilizes in pursuit of conformity in the long-term goals. Through the propaganda, the people devoted themselves to the goals that may not be realized in many years, even during their lives.

Propaganda integration, moreover, is subtler forms than the agitation which aims to strengthen cultural norms. It is sociological in nature as it provides stability to the community by supporting a way of life and myth in the culture. This is a propaganda of conformity that requires participation in the social body. This type of propaganda is more prominent and permanent, but it is not recognized as an agitation propaganda because propaganda of integration is more permanent. Basically, agitation propaganda provides motive power when needed and when not needed propaganda of integration provides context and background.

\section{Horizontal Propaganda}

Horizontal propaganda is a kind of propaganda which is done through the direct individual approach. Such propaganda is generally the most effective. It is mostly done in the membership of the group compared to the group leader. In other words, horizontal propaganda works among the membership of the group rather than the leader of the group; more often through interpersonal communication and orgazational communication rather than trough mass communication. Traditionally political parties rely on propaganda horizontally, such as a visit to the local organization committee, training of party cadres, conspiracy in prisons, and so on. Moreover, more through interpersonal communication and organizational communication are more effective than mass communication.

4. Vertical Propaganda

Vertical propaganda is propaganda that uses mass media as the main tool for influencing the public. This kind of this propaganda uses the news through newspapers, television, radio and others to deliver his message. Vertical Propaganda is generally regarded as a classic propaganda as it happens from the top down, from the leaders to the people, for example Nazi propaganda. The Leader acts like a technician, which is religious or political leaders who act from a position of authority. 
Propaganda is prepared in secret and uses methods of mass communication. The masses which are experiencing this propaganda are manipulated and coerced. In other words, they are dominated and passive. Vertical propaganda maybe represented by propagandists through speeches in front of a collection of their partisans, but now it is more often done through the mass media.

\section{DISCUSSIONS}

\section{The Kinds of Propaganda Used in The Novel}

In this part, the writer explains the kinds of propaganda and the purpose of propaganda contained in the novel. The data are taken from the novel "I Am Malala." The writer uses Jaqcues Ellul's theory and he divides four kinds of propaganda namely integration propaganda, horizontal propaganda and vertical propaganda.

a. Integration Propaganda

Propaganda of integration is propaganda that uses religion as a bridge, because religion is the doctrine of the strongest for all believers. The kinds of integration propaganda contained in the novel are following:

Based on Ellul's theory that says the propagandist uses the religion as the tool to convey their hidden purpose. It shows when Fazlullah introduces himself as reformer of Islam and reformer of Hadith. Through Islam, sometimes his voice was reasonable. He said men should keep their beards but give up smoking and using the tobacco they liked to chew. He said that the people should stop using heroin. He told the people that the correct way to do their ablutions for prayers. He even told the people how they should wash their private parts. In this data, the writer found that the propaganda of integration in explanation that depicted by Fazlullah. He tries to influence the Pakistani so that they can be interested in him and follow his teachings. It is shown in the following:

"In the beginning Fazlullah was very wise. He introduced himself as an Islamic reformer and an interpreter of the Quran. My mother is very devout, and to start with she liked Fazlullah. He used his station to encourage people to adopt good habits and abandon practices he said were bad." (Yousafzai \& Christina, 2013: 112).

The next quotation also shows the integrated propaganda. Taliban who hate another religion except Islam deliberately destroy the statues and stupas of Buddiest located on the hillside of Mingora because they assume that everything smelled Buddha did not deserve to be in that place. Moreover, they destroy everything and bring nothing new. It can bee seen in the following:

"The Taliban destroyed the Buddiest statues and stupas where we played, which had been there for thousands of years and were a part of our history from the time of the Kushan kings.

They believed any statue or painting was haram, sinful and therefore prohibited. One black day they even dynamited the face of the Jehanabad Buddha, which was carved into a hillside just half an hour's drive from Mingora and towered-three feet into the sky.” (Yousafzai \& Christina, 2013: 123-124).

Based on the above quotation, it can be concluded that propaganda integration operates by using Islam as an excuse. In this case Islam becomes the justification of the actions carried out by the Taliban as shown by the narrative in the novel. Through 
these two quotations, it can be interpreted that individual or groups of propaganda using religion is a strategy that is powerful to influence of religious communities.

b. Horizontal Propaganda

Horizontal propaganda is the kind of propaganda which is done through the directly individual approach. Such propaganda is generally the most effective. The kinds of horizontal propaganda contained in the novel are following:

The writers found the horizontal Propaganda is depicted through Muslim Khan, one of the figure of Taliban. He really does not like western culture so he directly told people that girls should not go to school and learned the ways of the western. He spoke western culture when he had lived so long in America. He wanted teachers and doctors for women, but does not allow women to go to school in order to have the qualifications for these two jobs. It can be seen as follows:

"Once Muslim Khan had said girls should not go to school and learn Western ways. This from a man who had lived so long in America! He insisted he would have his own education system.” (Yousafzai \& Christina, 2013: 162).

The writers also found horizontal propaganda which is depicted by Sufi Muhammad. Through the speech, he said that Pakistan is not an Islamic court. He said totally unexpected things. Sufi Muhammad said nothing about education. He didn't tell the Taliban to lay down their arms. Instead he appeared to threaten the whole nation. He just told his propaganda about Western democracy directly. "He described Pakistan's courts as un-Islamic, "I consider Western democracy a system imposed on us by the infidels. Islam doesn't allow democracy or elections." (Yousafzai \& Christina, 2013: 172).

Through these two quotations concluded that horizontal propaganda can be interpreted as an effort one to convey an ideology. This type of propaganda will have an effective impact if it is supported by the social status of the individual who delivered it. In other words, if the person conveying is influencaln society, then this propaganda will also have a great influence even if done by an individual. This is evidenced through the narrative text in the two quotations above.

c. Vertical Propaganda

Vertical propaganda is propaganda that uses mass media as the main tool to influence the public. This kind of propaganda uses the media such as newspaper, television, radio, etc. The writer found this propaganda which is shown by A deputy of Taliban, Shah Douran, delivers his propaganda on Mullah Radio. Through the propaganda, he said human actions sometimes angered God. Through the Mullah Radio he expressed his propaganda in a loud voice. He exploited their ignorance. Besides that, The writer also found vertical propaganda which is depicted by Dr. Raheela Qazi, one of the most vocal people against Malala on Yaseem's newspapers. She spread the photos of Malala beside President of America Barack Obama through the newspaper. She called Malala as American stooge. She was hopeful the spread of photographs could make the people hate Malala.

In another situation, the naration of teks shows vertical propaganda when the man told Ziauddin that the shopkeeper had given him a photocopied letter. He read it 
then his face become pale and said this is terrible propaganda against our school. The photocopy has been circulated. It contains a propaganda of Taliban addressed to the Muslims. The Taliban said that the Khushal School established by Malala's father has a very bad reputation. Through the photocopies, the Taliban exploit what actually happened. Taliban says Khushal School is the center of obscenity and obscene. This propaganda is done so that the Taliban have the support of people and can be immediately close Khushal School.

Based on the plot narrated through the text, it can be said that vertical propaganda is an effort made to influence society en masse. Propaganda carried out through mass media can be easily accepted by the public because of its very fast broadcasting and massive public impact. In the context above, propaganda through the mass media can be interpreted as a massive incitement because it can spread ideology in a very instant way so that the community was easily to be influenced.

\section{b. The impact of propaganda}

Based on the three kinds of propaganda, the writer can explain that although delivered through different media, all the three kinds of propaganda that have the mutual purpose of trying to steer public opinion to change the actions and expectations of the individual target.

The kinds of propaganda in the novel "I Am Malala" by Malala Yousafzai and Christina Lamb wants to change the actions and expectations of the individual target. The purpose of integration propaganda is to invite the Pakistani to follow the Talliban role by religion. Such as, when the Talliban using the name of Islam as the beginning of their propaganda. The purpose of horizontal propaganda is to invite the Paskitani by giving propaganda directly. Like in the novel when the Talliban collected the electronics of Pakistani and set them on fire. It is the one example of horizontal propaganda contained in the novel. And the vertical propaganda is used to invite the Pakistani by giving propaganda that used mass media. And it is the most effective propaganda is used in the novel because the Talliban use more this propaganda. The novel attempts to show how hard the group namely Taliban carrying out their propaganda and how hard a girl who called Malala also strongly opposed to the propaganda of the Taliban.

\section{CONCLUSION}

In "I Am Malala" novel by Malala Yousafzai and Christina Lamb, the author found several kinds of propaganda. The kinds of propaganda were deliberately created by the author to clarify the conflict that had occurred between The Taliban and the society. The author found there are three kinds of propaganda. Meanwhile the three kinds of propaganda are: a) Propaganda of integration the writer found is done by Fazlullah the leader of Talliban. He tries to influence the Pakistani so that they can interested with Talliban. In this propaganda also show that the Talliban destroyed all the things of Buddism doesn't deserve to be in that environment. The author used the propaganda integration in the novel, so that the reader can change the belief to something they had previously believed. b) Horizontal propaganda, the writer found 
explains how the Talliban shows propaganda in ways that are very hard. Such as, they collected the electronics of Pakistani and set them on fire, they against the education and many more. The author tried to describe how a person uses propaganda horizontally, so that the reader can use the same way to others. c) Propaganda vertical is the most powerful propaganda used by the Taliban in the novel. It means, propaganda vertically is the most effective propaganda is used in the novel. Talliban strengthen their propaganda through a photocopies to Pakistani. The author used propaganda vertical to show the readers that the mass media plays an important role to propaganda.

\section{REFERENCES}

Coxall, Malcolm. (2013). Human Manipulation. Cornelio Books: Spain.

Davis, Todd F. (2002). Formalist Criticism and Reader-Response Theory. New York Palgrave.

Ellul, Jacques. (1965). Propaganda: The Formation of Men's Attitudes. Trans. Konrad Kelen \& Jean Lerner. New York: Vintage Books Edition.

Gramsci, A. (1971). Selections from the Prison Notebooks of Antonio Gramsci. Q. Hoare \& G. N. Smith, eds. \& trans. London: Lawrence and Wishart.

Gardina, Lisa. (2005). Francis Bacon: Discovery and the Art of Discourse. Cambridge: Cambridge University Press.

Graham, Phil. (2006). Hypercapitalism: New Media, Language and Social Perception of Value.New York: Peter Lang.

Malesevic, Sinisa. (2010). The Sociology of War and Violence. Cambridge University Press. United States of America.

Marlin, R. (2013). Propaganda and the Ethic of Persuasion.(2 ${ }^{\text {nd }}$ Edition). New York: Broadview Press.

Miller, K. (2005). Communication Theories: Perspectives, Proseses, and Context. $2^{\text {nd }}$ edition. Ney York: McGrowraw Hill.

Miller, David. (2004). Tell Me Lies. USA: Pluto Press

Morley, Michael. (2002). How to Manage your Global Reputation. J.W. Arrosmith Ltd: Britain.

Muth, R. (2004). Harold D. Lasswell: An Annotated Bibliography. New Haven: New Haven Press.

Nelson, Richard Alan. (2006). A Chronology and Glossary of Propaganda in the United States. Pearson Education.

O’Donnell, Victoria. (2005). Propaganda and Persuasion. California: Sage Publications, Inc.

Yousafzai, Malala \& Lamb, Christina. (2013). I Am Malala: $1^{\text {st }}$ edition. New York: Little Brown. 2013. I Am Malala: $1^{\text {st }}$ edition. Trans. Ingrid Wijani. Bandung: Mizan. 